\title{
TOKSISITAS KADMIUM TERHADAP KESEHATAN IKAN
}

\author{
Hayatun Nufus ${ }^{1}$, Muhammad Radhi ${ }^{1}$ \\ ${ }^{1}$ Mahasiswa Program Studi Akuakultur. Fakultas Pertanian, Universitas Almuslim, Jalan Almuslim, Matang \\ Geulumpang Dua, Peusangan, Kabupaten Bireuen, Aceh 24261 \\ Email: hayatunnufus091098@gmail.com
}

\begin{abstract}
ABSTRAK
Toksisitas merupakan suatu efek yang merugikan dari bahan kimia dan bersifat negatif bagi semua ataupun sebagian makhluk hidup baik itu sel, jaringan, organ, individu ataupun populasi. Kadmium merupakan salah satu logam yang bila di dalam air tawar berbentuk ion $\mathrm{Cd} 2^{+}$. Beberapa faktor yang mempengaruhi kekuatan racun logam berat terhadap ikan adalah: bentuk ikatan kimia dari logam yang terlarut dalam air, pengaruh interaksi antara logam dan racun lainnya, pengaruh lingkungan seperti temperatur, kadar garam, dan pengaruh $\mathrm{pH}$ ataupun kadar oksigen dalam air, fase siklus hidup (telur, larva, dewasa), ukuran organisme, jenis kelamin, dan kecukupan kebutuhan bahan, kemampuan hewan untuk menghindar dari kondisi buruk, kemampuan ikan untuk beradaptasi terhadap racun, (misalnya proses detoksifikasi).
\end{abstract}

Kata Kunci: Toksisitas, kadmium, Organ-organ ikan.

\section{PENDAHULUAN}

Toksisitas merupakan suatu efek yang merugikan dari bahan kimia dan bersifat negatif bagi semua ataupun sebagian makhluk hidup baik itu sel, jaringan, organ, individu ataupun populasi. Efek yang ditimbulkan dapat merusak fungsi fisiologis dan struktur (Megawati, 2015). Meningkat nya kadar zatzat pencemar yang berbahaya dapat menimbulkan toksik atau racun sehingga mengganggu proses kehidupan dan setelah mencapai kadar tertentu dapat mematikan hewan peliharaan (Zulfahmi et al., 2017); (Zulfahmi et al., 2018); (Akmal et al., 2018d); (Muliari et al., 2019a); (Muliari et al., 2019b). Salah satu bahan pencemar yang dapat menimbulkan efek negatif bagi biota perairan adalah logam berat. Faktor lingkungan seperti toksik perairan dari dan kelainan genetik dapat mempengaruhi keabnormalan tulang rangka ikan (Zulfahmi et al., 2018); (Akmal et al., 2018a); (Akmal et al., 2018b); (Akmal et al., 2018c); (Akmal et al., 2019); (Zulfahmi et al., 2019). Bioata yang biasanya terpapar akan mengalami toksisitas akut ataupun kronis. Terdapat beberapa faktor yang mempengaruhi toksisitas yaitu konsentrasi toksin, durasi dan frekuensi pemaparan, komposisi dan sifat lingkungan (Megawati, 2015).

Toksisitas kronis akan terjadi apabila organisme terpapar oleh bahan kimia secara terus-menerus dalam suatu periode waktu yang panjang (Halang, 2004), factor yang mempengaruhi konsentrasi dari toksikan tersebut, sumber keluaran dan kecepatan masukan toksikan ke lingkungan, dan sifat fisik kimia biologis dari lingkungan. Kadmium (Cd) merupakan logam non essensial dan sekaligus mikro polutan yang tersebar luas dan mempunyai efek fisiologis pada organisme akuatik (Bambang et al., 1995).

Kadmium merupakan salah satu logam yang bila di dalam air tawar berbentuk ion $\mathrm{Cd}^{+}$. Toksisitas kadmium salah satunya dipengaruhi oleh salinitas, bila berada pada salinitas yang rendah konsentrasi ion $\mathrm{Cd}^{+}$meningkat. Hal ini berarti pada salinitas yang rendah toksisitas kadmium akan lebih tinggi dari pada salinitas yang tinggi (Rainbow et al., 1995). Untuk mengetahui tingkat pencemaran di suatu daerah dapat digunakan bioindikator berupa organisme perairan, yang dapat mengakumulasi bahan-bahan pencemar yang ada, sehingga dapat mewakili keadaan di dalam lingkungan hidupnya.

Beberapa faktor yang mempengaruhi kekuatan racun logam berat terhadap ikan adalah: bentuk ikatan kimia dari logam yang terlarut dalam air, pengaruh interaksi antara logam dan racun lainnya, pengaruh lingkungan seperti temperatur, kadar garam, dan pengaruh $\mathrm{pH}$ ataupun kadar oksigen dalam air, fase siklus hidup (telur, larva, dewasa), ukuran organisme, jenis kelamin, dan kecukupan kebutuhan bahan, kemampuan hewan untuk menghindar dari kondisi buruk, kemampuan ikan untuk beradaptasi terhadap racun, (misalnya proses detoksifikasi) (Darmono, 1993). Penyerapan logam oleh ikan akan diakumulasi pada jaringan tubuhnya terutama pada hepatopankreas dan insang (Bambang et al., 1995). Menurut Saputra (2013) insang ikan merupakan respirasi utama yang bekerja dengan mekanisme difusi permukaan dari gas-gas respirasi (oksigen dan karbohidrat) antara darah dan air, dengan demikian perubahan-perubahan lingkungan perairan akan secara langsung berdampak kepada struktur. Insang berperan pada proses respirasi, keseimbangan asam basa, regulasi ionik dan osmotik karena adanya jaringan epithelium branchial yang menjadi tempat berlangsungnya transport aktif antara organisme dan lingkungan (Soegianto et al., 1999). Hiperplasi yang diikuti dengan degenerasi dan nekrosis telah terbukti ada pada insang ikan yang terpapar logam berat dan perubahan-perubahan tersebut lebih terlihat pada paparan logam kadmium (Darmono et al., 1990). 
Menurut (Loomis 1979) Selain insang hati merupakan organ yang banyak berhubungan dengan senyawa kimia sehingga mudah terkena efek toksikan di karenakan diantara berbagai zat yang masuk bersama darah, kemungkinan besar ada zat yang dapat menyebabkan kerusakan hati. kadmium terakumulasi dalam ginjal, Menurut (Stine dan Brown 1996) ginjal merupakan bentuk zat-zat ekskresi yang tidak dibutuhkan tubuh seperti senyawa nitrogen, asam urat dan bahan-bahan beracun yang terbawa dalam system sirkulasi, mengatur keseimbangan, air dan elektrolit dalam tubuh dan mempertahankan keseimbangan asamasam basa menghasilkan hormone rennin. Organ selanjutnya yang terpapar yaitu pencernaan yang terjadi pada ( usus). (Menurut pratiwi dan Manan 2015). Usus adalah organ yang sering terpapar oleh agen-agen patogen dan parasit.agen -agen tersebut masuk kedalam usus mealului makanan yang masuk kedalam saluran pencernaan

\section{PEMBAHASAN}

\section{Kerusakan pada insang}

Tingginya kerusakan pada struktur insang dan hepatopankreas akan berpengaruh pada proses metabolisme enzim dan osmoregulasi pada ikan selain itu kerusakan pada sel yang disebabkan oleh keracunan kadmium atau factor lain sebagai contoh yaitu kondisi stress bisa meningkatkan sensitivitas terhadap infeksi viral dan bakteri (Snieszko, 1974). Insang berperan pada proses respirasi, keseimbangan asam basa, regulasi ionic dan osmotic karena adanya jaringan epithelium branchial yang menjadi tempat berlangsungnya transport aktif antara organisme (Soegianto et., 1999). Hiperplasi yang diikuti dengan degenerasi dan nekrosis telah terbukti ada pada insang ikan yang terpapar dan perubahan-perubahan tersebut lebih terlihat pada paparan logam kadmium (Darmono et al., 1990).

\section{Kerusakan pada hati}

Kerusakan yang terjadi pada organ hati ikan juga mendapatkan beberapa kerusakan, pada hati organ yang paling banyak mengakumulasi zat toksik sehingga mudah terkena efek toksik, sebagian zat toksit yang masuk setelah di serap oleh sel,akan dibawa kehati oleh vena porta hati sehingga hati berpotensi mengalami kerusakan, adanya zat toksik akan mempengaruhi struktur histology hati sehingga dapat mengakibatkan patologis hati (Camargo dan Martinez 2007).

\section{Kerusakan pada pencernaan (usus)}

Usus adalah organ yang sering terpapar oleh agen-agen patogen dan parasit, agen-agen tersebut masuk kedalam usus melalui makanan yang masuk kedalam saluran pencernaan menurut(Pratiwi dan Manan 2015). Beberapa kerusakan yang sering ditemukan pada usus ikan adalah proliferasi sel kerusakan yang banyak ditemukan pada usus ikan adalah nekrosis dan atropi pada lapisan epitel, deskuamasi epitel dan nekrosa dan hemoragi, hal tersebut diketahui diakibatkan oleh paparan toksin yang akut. (susanto, 2008;)

\section{Kerusakan pada ginjal}

Organ ginjal pada ikan berfungsi sebagai alat ekskresi dan osmoregulasi, ginjal mempunyai peranan penting dalam ekskresi sisa nitrogen dan mengatur keseimbangan (Piska dan Naik 1992). Bermacam-macam variasi dalam jumlah, bentuk, dan ukuran sel-sel ginjal, sel-sel ginjal besar jarang ditemukan, ginjal ikan yang kurang berkembang dengan baik, dan mungkin non-fungsional. (Pisska dan Naik 1992).

\section{KESIMPULAN}

Dari pembahasan tersebut dapat di simpulkan bahwa yang terkena pencemaran kadmium terhadap fisiologi ikan dapat merusak jaringan organ-organnya meliputi insang, menyebabkan kerusakan metabolisme enzim. Pada hati penyebabnya mudah terkena zat toksit yang terkena dibagian patalogis hati, dan kerusakan pada pencernaan usus pada nekrosis.

\section{DAFTAR PUSTAKA}

Akmal, Y., Saifuddin, F., \& Zulfahmi, I. (2018). Anatomi Skeleton Ikan Keureling. In Prosiding Seminar Nasional (Vol. 1, No. 1).

Akmal, Y., \& Rahardjo, M. F. (2018). Morphology of appendicular skeleton of the Thai mahseer's Tor tambroides (Bleeker, 1854). Jurnal Iktiologi Indonesia, 18(3), 261-274. https://doi.org/10.32491/jii.v18i3.443

Akmal, Y., Zulfahmi, I., \& Saifuddin, F. (2018). Karak-teristik morfometrik dan skeleton ikan keureling (Tor tambroides Bleeker 1854). Jurnal Ilmiah Samudra Akuatika, 2(1), 35-44.

Akmal, Y., Zulfahmi, I., Juanda, R., Karja, N. W. K., \& Nisa, C. (2018, December). Histopathological changes in gill of Nile tilapia (Oreochromis niloticus) after palm oil mill effluent exposure. In IOP Conference Series: Earth and Environmental Science (Vol. 216, No. 1, p. 012003). IOP Publishing.

Akmal, Y., Saifuddin, F., \& Zulfahmi, I. (2019). Karakteristik Morfometrik Dan Studi Osteologi Ikan Keureling. Prosiding Biotik, 5(1). 
Camargo, MMP, CBR Martinez. (2007). Histopathology of Gills, Kidneys and Liver of a neurotropical fish caged in an urban stream. Neorotropical Ichtiology, 5(3):327-336.

Darmono. (1993). Tatalaksana Usaha Sapi Kareman. Kanisius. Yogyakartadan atropi pada lapisan epitel.

Halang, B. (2004). Toksisitas Air Limbah Deterjen Terhadap Ikan Mas (Cyprinus carpio). Unlam press. Vol 1, nomor 1, 39-49.

Megawati, I. A. (2015). Uji Toksisitas Deterjen Terhadap Ikan Nila (Orechromis niloticus). Jurnal Skripsi.FKIP UMRAH. 1-10.

Muliari, M., Zulfahmi, I., \& Akmal, Y. (2019). Ekotoksikologi Akuatik. Bogor: IPB Press.

Muliari, M., Zulfahmi, I., Akmal, Y., Karja, N. W. K., Nisa, C., \& Sumon, K. A. (2019b). Effects of palm oil mill effluent on reproductive hormone of female nile tilapia, oreochromis niloticus (linnaeus 1758). Adv. Anim. Vet. Sci, 7(11), 1035-1041.

Stine, K.E. And Brown, T. M (1996) Principles of Toxicologi. CRCresslnc. Lewis publ.
Zulfahmi, I., Muliari, M., \& Akmal, Y. (2017, November). Indeks Hepatosomatik Dan Histopatologi Hati Ikan Nila (Oreochromis Niloticus Linnaeus 1758) Yang Dipapar Limbah Cair Kelapa Sawit. In Prosiding SEMDIUNAYA (Seminar Nasional Multi Disiplin Ilmu UNAYA) (Vol. 1, No. 1, pp. 301-314).

Zulfahmi, I,. Muliari, Akmal, Y,. Batubara AS. (2018) Reproductive performance and gonad histopathology of famale Nile Tilapia (Orechromis niloticusLinnaeus 1758). Exposed to palm oil mill effluent. The EgyptianJournal of Aquatic Research 44: 327-332.

Zulfahmi, I., Akmal, Y., \& Batubara, A. S. (2018). The morphology of Thai mahseer's Tor tambroides (Bleeker, 1854) axial skeleton (ossa vertebrae). Jurnal Iktiologi Indonesia, 18(2), 139-149.

Zulfahmi, I., Akmal Y., Muliari. (2019). Osteologi Ikan Keureling (Tor tambroides). Bogor: IPB Press; ISBN: 978-602-440-641-7 